\title{
MEMBANGUN PARADIGMA BARU PENGELOLAAN ZAKAT KOTA PALU DALAM PERSPEKTIF UU NOMOR 23 TAHUN 2011
}

\author{
Ahmadan B. Lamuri \\ Fakultas Agama Islam Universitas Alkhairat Palu \\ Email:amalanlan@yahoo.co.id
}

\begin{abstract}
Zakat is a potential instrument of Muslim common economy interest that needs managing though a particular institution. The presence of such institution shifts a traditional paradigm of zakat management: zakat was identical to ustadz and tended to be consumptive. And often, it was managed by a special committee. The descriptive analysis of data gained from primary and secondary source on the effort of BAZNAZ of Palu local government shows that BAZNAZ was founded as a commitment to implement acts of zakat in Indonesia. Further, it changed the paradigm of zakat management that focused more on ritual instead of social purpose. Whereas, zakat was aimed at reducing the number of poverty and other problems related to social welfare. Therefore, the presence of BAZNAS in Palu could change the paradigm of its citizens on term of muzakki, mustahik, and amil. Besides, it could overcome economic and social problems faced by Muslim in Palu.
\end{abstract}

Keywords: Paradigm, management of zakat, BAZNAS.

\begin{abstract}
Abstrak
Zakat merupakan instrumen ekonomi umat yang potensial dan membutuhkan pengelolaan yang profesional melalui lembaga yang dibentuk oleh yang berwenang. Terbentuknya lembaga pengelola zakat merupakan bagian dari upaya merubah paradigma masyarakat terhadap pola pengelolaan zakat yang selama ini dikembangkan dengan sistem tradisional (zakat identik dengan ustaz, bersifat konsumtif, dikelola dalam bentuk kepanitiaan, dan sebagainya). Melalui analisis deskriptif yang bersumber dari data pustaka (primer) dan data wawancara (sekunder) atas upaya pemerintah kota Palu dalam membentuk BAZNAS-nya ditemukan bahwa pembentukan BAZNAS adalah bagian dari komitmen pemerintah kota dalam merealisasikan peraturan perundang-undangan zakat di Indonesia; merubah pandangan atau paradigma masyarakat akan sistem pengelolaan zakat yang masih bertumpu pada pemenuhan kewajiban ritual semata tanpa memperhatikan manfaat sosialnya; dan juga mengharapkan hasil pengelolaan zakat melalui BAZNAS dapat memberi dukungan atas usaha pemerintah kota mengurangi angka kemiskinan serta masalah sosial lainnya yang bersentuhan dengan ekonomi warga. Diharapkan terbentuknya lembaga pengelola zakat kota Palu mampu merubah paradigma masyarakat terhadap makna muzakki, mustahik, dan amil; dan mampu memberi kontribusi positif bagi upaya penanggulangan masalah sosial ekonomi bagi umat Islam di kota Palu.
\end{abstract}

Kata K unci: Paradigma, pengelolaan zakat, BAZNAS. 


\section{Pendahuluan}

Zakat adalah salah satu ibadah dalam Islam yang berdimensi spritual personal, sosial, dan ekonomi. Zakat dianggap sebagai instrumen utama kebijakan fiskal negara yang digunakan untuk membangun masyarakat menjadi sejahtera dan bahkan zakat juga sebagai tatanan sosial ekonomi yang adil. ${ }^{1}$ Untuk kepentingan Negara, zakat dipandang sebagai pungutan atau pajak wajib dari si kaya yang didistribusikan kepada yang berhak. ${ }^{2}$ Hasil pengumpulan zakat harus dapat diberikan kepada yang berhak sebagaimana telah dijelaskan dalam al-Qur' apsurah al-T aubah (9) ayat (60).

B egitu jelasnya para pihak yang berhak menerima zakat dimana sejak kewajiban ini diturunkan kepada umat Islam sampai saat ini, nampaknya masih belum memberikan korelasi perubahan nasib mustahik dimaksud. Dilihat dari aspek pengelolaan, belum terdengar adanya kemajuan yang menggembirakan. Harapan perubahan yang semestinya jumlah kemiskinan semakin menurun dan jumlah wajib zakat semakin bertambah, tetapi justru saat ini angka kemiskinan di berbagai Negara yang mayoritas muslim pun masih menjadi problem Negara. Oleh karena itu, mekanisme manajemen pengelolaan harus mendapat perhatian serius dari setiap orang yang mempunyai wewenang atau mempunyai kekuasaan. Potensi penerimaan zakat di Indonesia (misalnya) diasumsikan bisa mencapai puluhan triliyunan bahkan mencapai ratusan triliyunan rupiah ${ }^{3}$. Hasil riset Baznas dan IPB potensi zakat Indonesia mencapai Rp. 217 triliun; akan tetapi sampai saat ini zakat yang terhimpun baru mencapai 1,2\% dari potensi yang ada atau sekitar Rp. 3 triliun. ${ }^{4}$

Di tengah besarnya potensi tersebut, faktanya saat ini peran Organisasi Pengumpul Zakat belum seutuhnya memberikan lampu terang yang semakin terang mengikuti perkembangan umat. Penghimpunan zakat melalui Badan A mil Zakat Nasional Pusat dalam laporannya setiap tahunnya mengalami perkembangan, dan bahkan lembaganya pun telah dianggap sangat baik dengan pola manajemen yang profesional modern. A kan

${ }^{1}$ Lihat: M uhammad \& Ridwan M as'ud, Zakat dan Kemiskinan Instrumen Pemberdayaan Ekonomi U mat, (Y ogyakarta: UII Press, 2005), 60.

2 Lihat: M uhammad Sharif Chaudhry, Sistem Ekonomi Islam Prinsip Dasar, (Jakarta: Prenadamedia, 2012), 79.

${ }^{3}$ Lihat: A rief Mufraini, A kuntansi dan Manajemen Zakat (Mengkomunikasikan Kesadaran \& M embangun Jaringan), (J akarta: K encana Prenada M edia, 2008), 136-137.

${ }^{4}$ Lihat: M edia A Ikhairat, K olom Dinamika, edisi Rabu, 10 A gustus 2016, 7. 
tetapi, pada tingkat daerah masih perlu didorong dan dilakukan sosialisasi berkesinambungan agar zakat dan pengelolaannya melalui institusi dapat secara terus menerus mendapatkan kepercayaan masyarakat.

Tentu pengelolaan yang profesional dan memiliki daya saing kompetitif tidaklah secepat membolak balik tangan; tetapi banyak menghadapi problematika. Di antara problem yang dihadapi dalam pengelolaan zakat adalah masih berkembangnya pemahaman dan paradigma yang bersifat tradisional misalnya: zakat urusan pribadi dengan T uhannya atau lebih cenderung urusan ibadah (ritual); zakat identik dengan ustaz yakni berzakat itu kepada seorang ustaz $\}$ yang dipercayai; ${ }^{5}$ karena zakat bersifat ibadah maka sistem pengelolaannya tidak perlu untuk diukur dengan menggunakan sistem ukuran yang baik. Selain itu, zakat juga disalurkan melalui pesantren dan masjid atau lembaga sosial Islam seperti panti anak yatim, dan tidak sedikit pula diserahkan langsung kepada fakir miskin ${ }^{6}$.

Sikap dan perilaku terhadap zakat yang demikian masih berkembang di kota Palu. Di Masjid Alkhairat (misalnya) proses pengumpulan zakat dilaksanakan setiap bulan Ramadhan dengan menetapkan beberapa orang sebagai panitianya. Di masjid lainnya (misalnya) Masjid al-Ittihad Keluruhan Ujuna Kec. Palu Barat, juga memberlakukan sistem kepanitian, namun dalam pengumpulannya hanya berlangsung pada saat bulan suci Ramadhan. Bila model dan pola seperti itu terus dikembangkan, maka zakat tidak akan nampak pengaruhnya bagi upaya pengentasan kemiskinan dan meningkatkan perekonomian umat Islam. Tentu kandungan makna zakat tidaklah demikian itu.

Untuk itulah dibutuhkan upaya merubah pemahaman, pemikiran, sikap dan perilaku yang selanjutnya menampilkan paradigma baru yang dapat menampung semua

\footnotetext{
${ }^{5}$ Penulis pernah membina Taman Pengajian al-Qur'an (TPQ) di Masjid Alkhairał Palu Sulawesi Tengah selama kurang lebih 10 tahun (1994-2004), memang pandangan masyarakat masih seperti yang digambarkan di atas; para orang tua murid lebih cenderung memilih menyerahkan zakatnya itu kepada para ustaz atau dewan guru lainnya yang mengajar dan mendidik anak-anak mereka. A lasannya singkat bahwa ustaz itu layak menerima zakat disebabkan mereka telah melakukan kegiatan yang berhubungan dengan fi sabiłillah. Kondisi ini masih saja terjadi di mana-mana; misalnya salah seorang pengurus Masjid Nur Alkhairał Palu dan juga Pembina Taman Pengajian al-Qur'an (TPQ) Ustaz Jabir mengatakan bahwa kebanyakan orang tua murid pengajian itu berzakat mendatangi guru-gurunya; wawancara, tanggal $08 \mathrm{Juni}$ 2016 di Palu.

${ }^{6}$ Lihat: Faisal S. A ttamimi, "Perspektif Masyarakat kota Palu terhadap Pengelolaan Zakat; dalam jurnal "Hunafa" vol. 5 nomor 3 (Desember, 2008), 370 menyebutkan bahwa mencapai 20\% muzakki menyerahkan zakatnya langsung kepada fakir miskin dan 35\% kepada imam masjid.
} 
kepentingan yang ada dalam sebuah wadah dan sistem yang dapat dipertanggung jawabkan kepada siapapun. U paya merubah sikap ini tidak lain adalah mengikuti

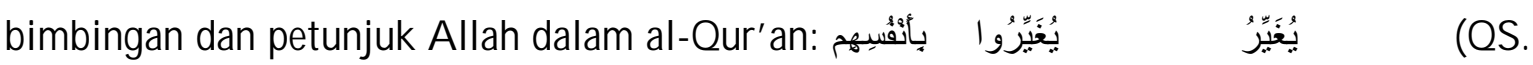
Al-Ra'd : 11).

Perubahan paradigma pengelolaan zakat harus ditopang oleh kesadaran untuk membangun kekuatan team atau kelompok tugas. Tentu lahirnya Badan A mil Zakat Nasional kota Palu yang baru dengan mendasarkan pada Undang-undang Zakat N omor 23 Tahun 2011 merupakan langkah merubah secara institusional dari yang sebelumnya berbentuk lembaga keagamaan semata menjadi lembaga pemerintah non struktural. Pembentukan B adan A mil Zakat Nasional yang baru tersebut nantinya sangat diharapkan atas perannya untuk menunjukkan pembangunan pengelolaan zakat yang memberi pengaruh bagi perkembangan masyarakat di kota Palu. Pemerintah kota Palu turut memberikan dukungan atas terbentuknya Badan Amil Zakat Nasional dimaksud agar sebagian tugas dan kerja pemerintah terutama dalam bidang sosial kemasyarakatan yakni upaya mengentaskan kemiskinan secara bertahap dapat teratasi. M erujuk pada Undangundang Zakat yang baru, telah menekankan akan peran pemerintah daerah, sehingga untuk membuktikan hal itu pemerintah daerah kota Palu melakukan kegiatan seleksi

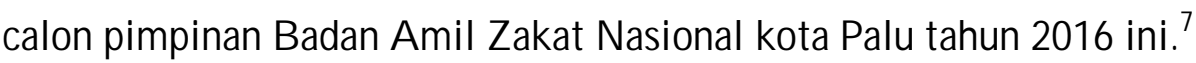

Kemiskinan, anak jalanan, anak yatim piatu komunitas masyarakat pinggiran yang merasa ekonominya melarat menjadi sasaran pembuktian akan adanya peran kelembagaan seperti itu. Jumlah kemiskinan di kota Palu yang masih mencapai \pm 15 ribu kepala keluarga, sebagaimana dalam data B adan Pusat Statistik tahun 2015 menunjukkan angka kemiskinan yang masih perlu mendapat perhatian serius. U paya pembentukan Badan A mil Zakat yang sesuai ketentuan yuridis formal akan diperhadapkan dengan kemampuan merubah hasil pengelolaan zakat. Selama ini khususnya yang berkembang di kota Palu, masyarakat masih menganggap bahwa zakat itu identik dengan ustaz sebagaimana yang berkembang di masyarakat umum di Indonesia. Oleh sebab itu, masalah yang perlu diselesaikan adalah bagaimana paradigma baru pengelolaan zakat yang perlu dikembangkan di kota Palu?

\footnotetext{
${ }^{7}$ A bdul Chaer (Wawancara), Palu, tanggal 09 J uni 2016. B eliau merupakan pegawai dan kepala Biro Kesra di Sekretariat Daerah kota Palu.
} 


\section{Pembahasan}

Paradigma Pengelolaan Zakat

Paradigma lama pengelolaan zakat seperti dikemukakan Ahmad Hasibuan yang dikutip oleh Hasanuddin dalam blognya ${ }^{8}$, meliputi: zakat kegiatan atau amalan yang bersifat sukarela dari orang kaya kepada yang miskin; zakat dibayarkan nanti telah mencapai satu tahun; zakat diperuntukkan bagi kyai, tuan guru, guru mengaji, dan atau orang-orang khusus lainnya; zakat karena bersifat sukarela, maka sistem penyerahannya pun langsung kepada orang per orang; zakat dikelola secara langsung dengan sistem distribusi ke penerima (konsumtif murni). Konsep seperti ini mengarahkan kepada tidak dibutuhkannya manajemen dalam mengelola zakat. Mungkin saja manajemen dalam pengertian praktis dapat saja diberlakukan tetapi manajemen dalam arti sebuah pengelolaan yang bagaikan mata rantai dari setiap kegiatan belum ditemukan.

Paradigma lama lainnya menyangkut manajemen zakat yang masih menganut paham: zakat berdasarkan prinsip tathawu' bukan ijbary; harusnya pengelolaan zakat membutuhkan regulasi yang terarah dan jelas sebagai payung hukum; tidak adanya database yang valid tentang kriteria dan jumlah muzakki dan mustahik; rujukan masih pada kitab-kitab figh klasik yang belum menjelaskan secara detail tentang kategori dan sifat dari delapan orang ashnaf; pengelola yang tidak secara resmi diangkat oleh pihak yang berwenang, sehingga pertanggung jawabannya dapat diterima sesuai syar'i dan aturan perundang-undangan; dan termasuk sumber daya manusia sebagai pengelola belum memenuhi standarisasi yang diharapkan. Paham yang demikian ini semua sudah saatnya dirubah dengan paham yang berorientasi bahwa zakat membutuhkan tata kelola yang multidimensi. Nilai spiritualnya tetap dipertahankan, tetapi nilai humanis sosial, ekonomi dengan pola manajemen profesional menjadi bagian prinsipil.

Selain yang telah dijelaskan di atas, termasuk pemahaman lama yang perlu dirubah adalah kurang jelasnya program kerja kelembagaan yang bersinergi dengan kebutuhan keummatan; pendayagunaan zakat belum berorientasi pada pengentasan kemiskinan secara nyata; belum terpolanya pemahaman umat terhadap peran lembaga pengelola zakat; dan bahkan termasuk yang belum dilakukan adalah mengkoordinasikan pengelolaan

${ }^{8}$ Hasanuddin \& M uhammad Ridha, 2013, Paradigma Baru Manajemen Zakat, dikutip dari Iaman: http://koneksi-indonesia.org/2013/paradigma-baru-manajemen-zakat/; diakses pada tanggal 25 M ei 2016. 
zakat secara institusional kepada lembaga yang mempunyai peran sama (baik pemerintah maupun non-pemerintah), yang seharusnya pola mengembangkan zakat dengan sistem terintegrasi secara terpadu?

Sahal Mahfud berpendapat bahwa terdapat banyak hal yang perlu ditata ulang terkait pengelolaan zakat. Pola pembayaran zakat yang masih terpencar; pembagian zakat yang belum memuaskan serta belum terkelola dengan pola manajemen modern; dan pengelolaan dalam bentuk kepanitiaan saja dianggap belum memberi kemajuan pengelolaan zakat. Oleh sebab itu, agar zakat menjadi kekuatan yang bermakna, maka perlu penataan dari aspek manajemen, pendataan, penyimpanan, pembagian bahkan kualitas manusianya dan selalu memperhatikan ketentuan syar'i harus ditampilkan dalam bentuk organisasi yang kuat dan rapi. ${ }^{10}$ Pandangan ini mengantarkan pada umat perlunya memperluas cakrawala melihat, mengelola, dan mengembangkan zakat sebagai bagian dari rukun Islam yang menjadi sumber wajib perekonomian umat Islam.

Untuk itu, pandangan dan paham yang demikian di atas itu, tidak akan menunjukkan kemajuan dan pengaruh bagi kondisi mustahik yang ada. Kondisi ini membutuhkan upaya merubah paradigma seluruh komunitas dalam pengelolaan zakat. Undang-undang Nomor 23 Tahun 2011 pada konsideran menimbang di point (d) dinyatakan bahwa dalam rangka meningkatkan daya guna dan hasil guna, zakat harus dikelola secara melembaga sesuai dengan syari'ah Islam.

Sementara paradigma baru dalam pengelolaan zakat secara umum dapat dilihat pada beberapa hal, yaitu:

\section{Paradigma M uzakki}

Muzakki sebagai orang yang diberikan kewajiban untuk membayar zakat sangat penting dipahami; hal ini disebabkan oleh dari merekalah asal muasal harta zakat itu. K ewajiban zakat disebabkan oleh adanya kelebihan harta kekayaan yang dapat digunakan untuk menutupi kebutuhan hidupnya. Oleh sebab itu, muzakki harus dapat dilihat pada dua peran dan posisi utama dalam pengelolaan zakat.

\footnotetext{
${ }^{9}$ Undang-undang N omor 23 Tahun 2011 tentang Pengelolaan Zakat pasal 2.

${ }^{10}$ Lihat: Sahal M ahfudh, Nuansa Figh Sosial, (Y ogyakarta: LK iS, 1994), 145-146.
} 
Pertama, muzakki sebagai sumber harta zakat yang nantinya menjadi instrumen peningkatan ekonomi umat. Peran ini menuntut adanya upaya berkesinambungan terhadap penggalangan sejumlah muzakki. Semakin banyak muzakki yang direktrut, maka peluang mendatangkan anggaran belanja pun akan semakin besar yang akhirnya memberi pengaruh pada banyaknya jumlah kelompok mustahik yang menerima manfaat. Sahal Mahfudh menekankan bahwa aspek pendataan muzakki serta harta yang dimilikinya menjadi sesuatu yang dilaksanakan secara cermat agar dengan cara seperti itu menghilangkan keengganan membayar kewajibannya. ${ }^{11}$ Merubah paradigma muzakki yang demikian itu juga menjadi salah satu gambaran program yang ditawarkan oleh calon pimpinan Badan A mil Zakat Nasional kota Palu, di antaranya: A milin A. Bulungo dengan konsep menyediakan fasilitas untuk memudahkan muzakki dalam memperoleh akses informasi; melakukan kerjasama dengan lembaga keuangan, media massa dan media elektronik dalam rangka membangun sistem transparansi pengelolaan baik untuk diketahui pada para muzakki maupun publik. ${ }^{12}$

Djasman Latima juga sebagai calon pimpinan mengatakan bahwa pengelolaan yang ada sekarang belum memberi dampak besar bagi upaya mensejahterakan kelompok fakir dan miskin; hal ini disebabkan oleh pengelolanya yang masih seperti kepanitiaan semata kalaupun dalam bentuk pengurus masih belum sesuai sumber daya manusia pengelolanya dengan beban tugas dan tanggungjawab. Sistem yang ada saat ini dengan pengurus menggunakan beberapa orang pimpinan akan lebih baik lagi yang nantinya dapat menanamkan kepercayaan muzakki. ${ }^{13}$

Pandangan di atas sebenarnya menginginkan dan mengharapkan bahwa pengelolaan zakat di masa mendatang harusnya mampu melahirkan kepercayaan para muzakki. Mengelola lembaga yang dapat dipercayai oleh masyarakat atau umat hanyalah bila lembaga itu dikelola dengan tata kelola yang handal dengan sumber daya manusia yang profesional. Oleh sebab itu, kedua calon pimpinan yang ada telah merencanakan melakukan penataan pengelolaan zakat kota Palu yang didasari atas merubah pandangan

${ }^{11}$ L ihat: Sahal M ahfudh, Nuansa.....h. 149.

12 Lihat: A milin A. Bulungo, Menata M anajemen BAZNAS dalam Mengentaskan Komiskinan Berbasis Pemberdayaan Masyarakat di kota Palu, (makalah) disampaikan dalam kegiatan seleksi Calon Pimpinan BAZNA S kota Palu (J uni, 2016), h. 6.

${ }^{13}$ Djasman Latima,W awancara, tanggal 09 J uni 2016, di Palu. 
masyarakat ke arah tata kelola yang amanah. Gagasan dimaksud adalah bagian dari upaya merubah paradigma yang selama ini berkembang; termasuk di dalamnya para muzakki.

Kedua, muzakki harus dipahami bahwa mereka sebagai subyek pengelolaan yang diharapkan selalu bersama dengan amil dalam rangka mengawal kelancaran distribusi hartanya sebagaimana tujuan zakat itu sendiri. Memang muzakki tidak ada peran dan posisinya untuk melakukan pengawalan atau pengawasan terhadap pengelolaan, tetapi salah satu upaya untuk membangun kerjasama pengawasan, sehingga kegiatan pendistribusian, pendayagunaan dapat disaksikan dan dirasakan pembayar zakat. ${ }^{14}$

Keterlibatan dimaksud tergantung pada strategi yang dibuat oleh amil. Namun, tujuannya adalah memberi kesan kepercayaan, sehingga para muzakki selalu terpanggil untuk membayar kewajibannya tanpa harus didatangi lagi oleh amil atau bahkan sikap menunda-nunda pembayaran zakatnya tidak lagi dilakukannya.

Selain posisinya sebagai subyek yang menjadi sumber dan asal mula harta zakat, ia juga merupakan konsep yang saling kait-mengait dengan konsep harta. Paradigma tentang muzakki kebanyakan masih tertuju pada individu wajib zakat. Padahal ada dua metode yang dilakukan oleh para ulama untuk menjelaskan siapa muzakki. Pertama, menjelaskan kriteria wajib zakat berikut syarat sahnya ${ }^{15}$. Kedua, menjelaskan kriteria obyek harta yang dikenakan hukum zakat ${ }^{16}$. Paradigma baru tentang muzakki menitik beratkan pada pengembangan harta obyek zakat sebagaimana telah dijelaskan dalam kajian fiqh zakat tradisional dan kontemporer; hal ini dilakukan mengingat banyak kegiatan atau aktifitas manusia yang telah menghasilkan harta kekayaan yang karenanya dapat diperhitungkan sebagai bagian dari ketentuan yang dikenai kewajiban zakat, misalnya: adanya usaha profesi dan lainnya. Sedangkan subyek zakat terdiri atas individu dan badan usaha. ${ }^{17}$

\footnotetext{
${ }^{14} \mathrm{M}$ enurut Qadry Azizy, bahwa perlu pembayar zakat (muzakki) mengetahui kemana zakatnya itu dibagikan dan dimanfaatkan; disinilah dibutuhkan dokumen atau pembukuan oleh Amil sebagai upaya membangun kepercayaan dengan muzakki dan sekaligus keterlibatan muzakki secara tidak langsung dalam pengelolaan zakat ( $M$ embangun Fondasi Ekonomi U mat, M eneropong Prospek Berkembangnya Ekonomi Islam, (Y ogyakarta: Pustaka Pelajar, 2004), 144-145.

${ }^{15}$ Lihat: Wahbah al-Zuhaily, Fiqh al-Islam wa A dillatuhu jilid 3, (terj.) A bdul Hayyie, dkk. (Depok; Gema Insani Press, 2011), 172-182.

${ }^{16}$ L ihat: T.M. Hasbi ash-Shiddiegy, Pedoman Zakat, edisi 3 (Semarang: Rizki Putra, 2009), 17-18 \& 33. M uhammad Jawad M ughniyah, Fiqh Lima M azhab (terj.), (J akarta: L entera, 2011), 180-188.

17 Lihat: Undang-undang N omor 23 Tahun 2011 pasal 4 ayat $(1,2, \& 3)$.
} 
Jumlah individu yang telah memenuhi syarat atau dikenakan kewajiban zakat untuk kota Palu belum ditemukan data riil sebagaimana layaknya wajib pajak. Hal ini membutuhkan langkah aktif melakukan pendataan, sehingga muzakki dapat teridentifikasi melalui database dan ini akan memudahkan dilakukan evaluasi dampak dari pemenuhan kewajibannya. Esensi zakat menekankan pada kesucian, keberkahan, dan tumbuh berkembang. ${ }^{18}$ Oleh sebab itu, tujuan untuk mendata adalah bagian dari usaha mengevaluasi tingkat perubahan kehidupannya. Esensi zakat yang demikian itu memberi nilai positif bagi pelakunya agar hidup dalam kesucian dan bahkan ada proses bertambahnya kehidupannya yang lebih baik lagi. ${ }^{19} \mathrm{Hal}$ serupa harus diberlakukan pada badan usaha seperti diamanahkan dalam Undang-undang Nomor 23 Tahun 2011. K husus badan usaha berdasarkan ketentuan Peraturan Pemerintah Nomor 14 Tahun 2014 sebagai penjelasan atas UU Nomor 23 Tahun 2011 tersebut bahwa lingkup kewenangan Badan A mil Zakat Nasional tingkat Kabupaten/K ota di antaranya Badan U saha milik Daerah, Perusahaan Swasta skala kabupaten, Satuan Kerja Perangkat Daerah (SKPD), dan lain sebagainya. ${ }^{20}$

\section{Paradigma M ustahik}

Mustahik sebagai kelompok penerima zakat secara teks sangat simple untuk dimaknai dan dipahami. Tetapi bila didistribusikan ke dalam pemaknaan serta penjelasan lebih lanjut akan ditemukan beragam konsep atas mustahik yang delapan kelompok tersebut. Hasil pengembangan pemaknaan dimaksud akan berdampak terhadap upaya mendistribusikan hasil pengumpulan zakat secara keseluruhan kepada para mustahik dimaksud. Tentu urutan yang dijelaskan dalam al-Qur'an tentang mustahik dijamin mempunyai tingkat dan proporsi yang berbeda. Implikasinya dalam sistem distribusi harus memperhatikan kedudukan masing-masing mustahik atau menggunakan pola pendistribusian dengan memperhatikan skala prioritas.

Jika selama ini dipahami bahwa mustahik adalah kelompok manusia yang mempunyai hak atas pengumpulan harta zakat, maka harus dirubah pola dan pengelolaan

${ }^{18}$ Lihat: M uslim, Sq̣hih M uslim jilid 7, (Daßal-Fikr, t.th.), 48-51. Lihat: Ibnu Hajar al-A sqalany, Subulussal am J uz II, (M aktabah al-J umhuriyah al-A rabiyah, t.th.), 159. Lihat: N urul Huda (et.al), K euangan Publik Islami Pendekatan T eoritis dan Sejarah, (J akarta: K encana, 2012), h. 88.

${ }^{19}$ Li hat: A hmadan B. L amuri, K onsepsi Hukum Islam tentang A mil Zakat dan Korelasinya dengan Undang-undang N omor 38 T ahun 1999, tesis (tidak diterbitkan); (M akassar, IA IN A lauddin, 2004), 21.

${ }^{20}$ L ihat: Peraturan Pemerintah Nomor 14 Tahun 2014 pasal 55 ayat (2). 
kelompok dimaksud dengan meningkatkan kapasitas pada masing-masing kelompok sehingga dari mustahik menjadi muzakki. Kefakiran, kemiskinan, terlilit hutang, atau pekerja dalam rumah tangga yang mendapat upah atau gaji dibawah standar minimum harus diyakini ini semua hanyalah kondisi sesaat yang memungkinkan untuk dirubah melalui sistem edukasi, pendayagunaan serta distribusi yang mengarah ke produktif. A bdul Wahab Muhaimin mengatakan pendayagunaan zakat kearah produktif bertujuan untuk mengangkat harkat dan martabat kemanusiaan para mustahik (khususnya fakir \& miskin) yang akhirnya mereka semua dapat menjadi muzakki. ${ }^{21}$

Pola edukasi bertumpuh pada pemberian pemahaman bahwa tangan di bawah itu kurang memberi nilai manusiawi atau menunjukkan harkat kemanusiaan yang kurang baik. Islam telah mengajarkan bahwa kerja keras merupakan sarana mendapatkan harta. U saha yang sungguh-sungguh dan ditopang dengan ilmu pengetahuan akan mengantarkan seseorang meraih impiannya. Y usuf al-Q ardhawi mengatakan bahwa beramal yang banyak dianjurkan Islam kepada umatnya menekankan pada usaha serius baik bersifat individu maupun kolektif untuk menghasilkan barang ataupun pelayanan; dan usaha atau bekerja keras adalah senjata pertama memerangi kemiskinan. ${ }^{22}$

Dimisalkan, ketika zakat harus didistribusikan kepada kaum miskin, maka akan timbul sebuah pertanyaan, standar kriteria untuk menentukan seseorang itu termasuk orang miskin bagaimana. Selama ini sistem distribusi zakat kepada miskin telah dilakukan tetapi belum ada data konrit menyatakan bahwa dengan distribusi secara langsung selama ini terhadap si miskin telah terjadi penurunan angka kemiskinan. Karena itulah, perlu adanya wawasan lebih ke depan bahwa miskin pun masih membutuhkan analisis yang tepat agar distribusi zakat dapat memberi pengaruh positif bagi penurunan angka kemiskinan. Pelibatan Badan Pusat Statistik dan lembaga lainnya yang terintegrasi dapat mendeteksi kondisi kemiskinan umat menjadi suatu usaha harus dilakukan.

Contoh lain dalam sistem distribusi dana zakat yang penting dilaksanakan kepada mustahik antara lain: bentuk konsumtif semata, mungkin ini hanya akan dapat diberlakukan bagi kelompok mustahik yang dari berbagai sisi kehidupannya sangat sulit

\footnotetext{
${ }^{21}$ Lihat: A bdul W ahab M uhaimin, K ajian Islam A ktual, (J akarta: Gaung Persada Press, 2011), 43.

${ }^{22}$ Lihat: Y usuf al-Qardhawi, "Teologi Kemiskinan Dokrtin Dasar \& Solusi Islam atas Problem Kemiskinan, (terj.) oleh A. M aimun \& A. Wahid, (Y ogyakarta: Pustaka Pelajar, 2002), 70-71.
} 
untuk dirubah. Tetapi paradigma baru melihat mustahik harusnya tetap mempertimbangkan prinsip bahwa manusia memiliki potensi yang sangat luar biasa melebihi makhluk lainnya; yang dengan potensi tersebut dapat dimanfaatkan untuk kemajuannya. ${ }^{23}$ B entuk konsumtif ini hanya dapat diberlakukan bagi kelompok fakir dan miskin sebagaimana makna keduanya yang serba kekurangan. Walaupun tetap harus diprioritaskan untuk didayagunakan potensinya sebagai seorang manusia yang berhak menerima zakat. ${ }^{24}$ Bentuk pemberdayaan, merupakan penyaluran zakat yang disertai target merubah keadaan penerima dari kondisi kategori mustahik menjadi muzakki. Target ini adalah target besar yang tidak dapat mudah dan dengan waktu yang singkat. Untuk itu, penyaluran zakat harus disertai dengan pemahaman yang utuh terhadap permasalahan yang ada pada penerima. Kondisi ini dapat saja berbentuk penundaan pendistribusian zakat kepada ashnaf untuk digunakan dalam kegiatan produktif melalui investasi. Hasil investasi (keuntungan) itulah yang nantinya didistribusi ke mustahik. ${ }^{25}$

Oleh sebab itu, paradigma baru yang penting dibangun dalam pengelolaan mustahik adalah mendasarkan pada skala prioritas kebutuhan di antara mereka. Sjechul Hadi Permono mengatakan bahwa ketentuan tentang delapan ashnaf yang berhak menerima zakat, berlaku kategori-kategori bukan secara keseluruhan langsung mendapatkan bagian, tetapi dari aspek konseptual menuntut diutamakannya di antara mereka yang lebih membutuhkannya. ${ }^{26}$ Zakat yang mempunyai tujuan sosial tentu harus dikelola dengan harapan berubahnya keadaan mustahik dari sebagai penerima menjadi pembayar zakat (muzakki). Huzaemah T.Y anggo menyatakan bahwa upaya pendayagunaan zakat dalam penanggulangan kemiskinan adalah untuk meningkatkan harkat dan martabat

${ }^{23}$ Lihat: Pandangan M urthadha M uthahhari yang menyatakan bahwa manusia memiliki dua potensi yang berbeda dengan binatang (makhluk lainnya) yaitu: memiliki kecenderungan spiritual yang dapat memperluas aktifitasnya sampai ke cakrawala spiritualitas yang lebih tinggi; dan memiliki daya kehendak yang dapat menentukan batas kecenderungannya (M urthadha M uthahhari, "M anusia dan Alam Semesta K onsepsi Islam tentang J agat Raya, (terj.) oleh Ilyas Hassan, (J akarta: Lentera, 2006), 228.

${ }^{24}$ Wahbah al-Zuhaili mengatakan bahwa fakir \& miskin merupakan orang pada asalnya tidak memiliki harta kekayaan, pekerjaan yang layak, atau mempunyai harta kekayaan tetapi harta dimaksud tidak mencukupi untuk menutupi kebutuhan hidupnya: Zakat Kajian Berbagai Mazhab, terj. oleh A gus Effendi, (B andung: Remaja R osdakarya, t.th), 296-297.

${ }_{25}$ L ihat: Oni Sahroni \& A diwarman K arim, 2015, M aqashid Bisnis \& K euangan Islam Sintesis Fikih dan Ekonomi, ( Jakarta: Rajawali Press, 2015), 177-178.

${ }^{26}$ L ihat: Sjechul Hadi Permono, Formula Zakat M enuju Kesejahteraan Sosial, (Surabaya: CV . A ulia, 2005), 276. 
kemanusiaan fakir dan miskin agar mereka keluar dari belenggu kefakirannya ke taraf hidup yang layak dan pada akhirnya kehidupannya meningkat dari status sebagai mustahik menjadi muzakki. ${ }^{27} \mathrm{~K}$ iflin Padjala selaku wakil ketua Panitia Seleksi Pimpinan Badan A mil Zakat kota Palu menyatakan bahwa harapan dibalik pembentukan BAZNAS kota Palu melalui seleksi calon pimpinannya adalah kemampuan mereka yang terpilih merubah kondisi umat yang hanya besar ketergantungan hidup dengan pemberian dan bukan pada hasil usaha sendiri. Kondisi itu merupakan bagian dari tantangan yang harus diselesaikan oleh pimpinan BAZNAS kota Palu nantinya. ${ }^{28}$

3. Paradigma A mil

A mil termasuk salah satu dari delapan kelompok yang berhak menerima zakat. A mil dimaksudkan adalah orang yang bekerja memungut zakat ${ }^{29}$, atau orang-orang yang diangkat untuk memungut zakat dari pemiliknya. ${ }^{30}$ Dilihat dari aspek posisi dan peran, sebenarnya amil merupakan kelompok atau komunitas yang dipercayakan untuk mengurus zakat itu sendiri. Ini menunjukkan bahwa posisi amil sangat menentukan keberhasilan pengelolaan zakat. Selama ini amil hanya dipahami sebagai komunitas penerima zakat, sehingga rutinitas kegiatannya sebatas pada pengumpulan sesaat kemudian hasil pengumpulannya dibagikan kepada komunitas lainnya. Peran dan kedudukan amil sangat strategis dalam tata kelola zakat. Namun, paradigma yang perlu dikembangkan ke depan terhadap pengelolaan zakat adalah kemampuan melakukan upaya untuk memperluas dan memperbanyak jumlah pembayar zakat dan mengubah kondisi sebagian besar fakir miskin menjadi orang yang berkecukupan dan memiliki sesuatu sepanjang zaman. ${ }^{31}$

A mil sebagai salah satu dari mustahik harus dipahami berbeda dengan mustahik lainnya. M emang dari aspek normative nampak kalau amil sama dengan mustahik lainnya, tetapi mendasarkan pada makna yang dikandung, maka amil secara otomatis menuntut adanya pelembagaan. ${ }^{32} \mathrm{M}$ emang sebelum pelembagaannya, peran amil masih melahirkan

${ }^{27}$ Lihat: Huzaemah T.Y anggo, Masail Fiqhiyah, Kajian Hukum Islam Kontemporer, (Bandung: A ngkasa, 2005), 225

${ }^{28} \mathrm{~K}$ iflin Padjala, Wawancara, tanggal 09 Juni di Palu.

${ }^{29}$ Lihat: Wahbah al-Zuhaili, Zakat......, 282.

${ }^{30}$ Lihat: Sjechul Hadi Permono, Formula......, 257. A mil zakat adalah sesuatu yang penting bahkan pemerintah memiliki kewajiban untuk menugaskan para pemungut zakat. Lihat: Y usuf al-Q ardhawi, Hukum Zakat (terj.) oleh Salman Harun \& Didin H afidhuddin (Bandung: M izan, 1996) 545-546.

31 Lihat: Y usuf al-Q ardhawi, Hukum.....,229. Lihat: Huzaemah T. Y anggo, M asail... ., 225.

32 Untuk kelangsungan zakat dibutuhkan peranan organisasi dan kekuasaan yang mengatur serta mengayomi masyarakat. Proses ini dilakukan oleh amilin dan khalifah atau imam. Lihat: Ali Yafie, 342 | al-Maslahah: - Volume 12 Nomor 2 Oßtober 2016 
pro kontra di kalangan para ulama; ada yang menyatakan bahwa zakat lebih baik diserahkan secara langsung oleh para wajib zakat kepada penerima; tetapi ada juga yang mengatakan pembentukan lembaga amil oleh penguasa belum sepenuhnya dipercaya dengan alasan pemerintahan yang ada bukan pemerintahan Islam. ${ }^{33}$

Qadry Azizy mengemukakan bahwa pengelolaan zakat sangat membutuhkan regulasi. A danya regulasi akan memberi penegasan terhadap proses pengumpulan dan pendistribusian zakat. Walaupun menurutnya, bahwa apakah bentuk regulasinya itu bersifat memaksa atau hanya sekedar anjuran tetapi yang terpenting zakat sebagai dana umat perlu dikelola dengan penuh tanggung jawab. ${ }^{34}$ Sesuai dengan sifat kewajiban zakat yang harus dilaksanakan dengan pasti, maka penanganannya harus diimplementasikan dalam suatu tugas operasional oleh suatu lembaga yang fungsional sebagai administrator dan manajemen zakat. ${ }^{35}$ Oleh karena itu, sebagai upaya merealisasikan komitmen kelembagaan amil zakat, maka pemerintah telah membuat regulasi pengelolaan zakat nasional. Tentu adanya regulasi zakat nasional merupakan langkah maju dan positif (terlepas dari masih adanya kekurangan dalam aturannya) untuk mengembangkan dan menata zakat lebih profesional dan mendatangkan keberhasilan yang lebih baik di tahuntahun mendatang. Bila disimak isi Undang-undang zakat yang baru terdapat banyak hal yang harus dilakukan dalam pengelolaan zakat. Termasuk paradigma barunya adalah mengelola zakat dengan menggunakan asas terintegrasi. ${ }^{36}$ Ini menunjukkan bahwa tata kelola zakat yang dilakukan oleh amil zakat nantinya harus melibatkan banyak pihak, komunitas, organisasi (lembaga), serta sistem yang terpadu dalam kesatuan manajemen.

Dengan demikian, pembentukan kelembagaan pengelola zakat dengan mendasarkan pada regulasi yang ada secara langsung menekankan pentingnya manajemen zakat. A mil sebagai lembaga, diharapkan mampu mengelola zakat dengan manajemen sebagai alatnya. M anajemen zakat tidaklah berbeda dengan sistem pengelolaan unit usaha atau organisasi

M enggagas Fiqh Sosial dari Soal Lingkungan Hidup, A suransi, hingga U khuwah, (Bandung: M izan, 1992), 233.

${ }^{33}$ Lihat: A bdurrachman Qadir, Zakat dalam Dimensi Mahdhah \& Sosial, (Jakarta: Raja Grafindo Persada, 2001), 166-167. Lihat: Y usuf Wibisono, M engelola Zakat Indonesia, Diskursus Pengelolaan Zakat Nasional, (J akarta: Prenada M edia Group, 2015), 142-144.

${ }^{34}$ Li ihat: Qadry Azizy, M embangun.... .. 149-150.

${ }^{35}$ Lihat: A bdurrachman Qadir, Zakat..... 169.

${ }^{36}$ L ihat: UU Nomor 23 Tahun 2011 pasal pasal 2. 
lainnya. Kecuali pada materinya saja yang berbeda. Penggunaan manajemen dalam pengelolaan zakat akan mengarahkan amil untuk dapat lebih menata pengembangan zakat menjadi lebih maju dan lebih memberl kontribusi perekonomian bagi umat. Seluruh proses pengelolaan zakat didasarkan pada manajemen. $M$ anajemen akan digunakan dalam mencapai visi, misi, dan tujuan organisasi.

Pelembagaan zakat dengan menggunakan sistem manajemen diharapkan mampu melahirkan sikap para amil untuk berusaha meningkatkan tata kelola zakat yang lebih produktif melalui kegiatan pendayagunaan zakat itu sendiri. Pendayagunaan yang selama ini dilakukan sebagaimana yang dijelaskan oleh Huzaemah T. Y anggo adalah:

1. Pendayagunaan yang konsumtif tradisional yaitu zakat dibagikan kepada mustahik untuk dimanfaatkan langsung oleh yang bersangkutan;

2. Pendayagunaan zakat yang bersifat konsumtif kreatif yaitu penerimaan zakat diwujudkan dalam bentuk alat-alat sekolah, beasiswa, dan lain sebagainya;

3. Pendayagunaan zakat yang bersifat kreatif tradisional yaitu zakat diberikan dalam bentuk barang produktif;

4. Pendayagunaan zakat bersifat produktif kreatif yaitu zakat diwujudkan dalam bentuk modal usaha yang dapat digunakan untuk membangun suatu proyek usaha mustahik. $^{37}$

Memperhatikan realisasi pendayagunaan yang selama ini dilakukan oleh pengelola zakat, maka perlu ditekankan bahwa pendayagunaan kearah produktif kreatif menjadi prioritas dalam mendistribusikan hasil pengumpulan zakat. Walaupun demikian, analisis tingkat kebutuhan dan kondisi riil mustahik menjadi bagian dari sistem evaluasi. ${ }^{38} \mathrm{U}$ saha pendayagunaan dimaksud adalah usaha yang mampu meningkatkan dua hal pada mustahik, yakni: peningkatan pendapatan, taraf hidup, kesejahteraan masyarakat, dan peningkatan kualitas umat yang lebih mengarah pada sumber daya manusianya ${ }^{39}$.

A mil harus mampu melakukan terobosan pemanfaatan zakat dengan target melahirkan jumlah mustahik yang menjadi muzakki. Hal ini dapat dicapai apabila pola

\footnotetext{
${ }^{37}$ L lihat: Huzaemah T. Y anggo, M asail...., 226.

38 Lihat: UU Nomor 23 Tahun 2011, pasal 27.

${ }^{39}$ Lihat: Penjelasan UU Nomor 23 Tahun 2011 pasal 27. Lihat lebih Ianjut dalam A rief M ufrani, A kuntansi....., 160-162.
} 
pengelolaan zakat beralih dari sistem tradisional konsumtif atau habis pakai menjadi modal yang terus menerus mengalami perkembangan. Pendayagunaan adalah langkah dan tindakan yang semestinya dilakukan mengingat bahwa pendayagunaan itu sendiri bertujuan untuk meningkatkan harkat dan martabat kemanusiaan fakir miskin. ${ }^{40}$ W alaupun dalam rangka pendayagunaan dimaksud, bagi amil tetap memperhatikan skala prioritas kebutuhan mustahik yang dapat dimanfaatkan untuk kegiatan produktif. ${ }^{41}$

\section{U saha M embangun K omitmen M erubah Pola Pengelolaan}

Reinterpretasi tata kelola zakat sangat urgen seiring dengan tuntutan yuridis normative yang telah dilegalisasikan pemerintah. Tentu kehadiran peraturan perundangundangan zakat yang baru (sebagai hasil review UU Nomor 38 Tahun 1999) merupakan jawaban atas esensi dari amil yang telah disebutkan secara formal dalam al-Qur'an. Oleh sebab itu, kehadiran amil dalam tata kelola zakat sangat menentukan keberhasilan atas kewajiban zakat di kalangan kaum muslimin. U paya optimalisasi sistem zakat sebagai salah satu proses redistribusi income, maka posisi amil di antara mustahik yang ada mempunyai peranan yang luar biasa. Keberhasilan tata kelola zakat akan banyak bergantung pada profesionalismenya amil. Semakin tinggi tingkat profesionalismenya, maka tingkat kesejahteraan mustahik pun akan semakin lebih baik. Artinya termasuk angka kemiskinan secara otomatis dapat diturunkan. ${ }^{42}$

Ketradisionalan pengelolaan zakat ${ }^{43}$ selama ini harus dijadikan barometer membangun kerangka kerja yang baru guna mewujudkan manfaat zakat yang lebih besar bagi kehidupan umat pada khususnya dan daerah serta bangsa pada umumnya. Prinsip membiarkan zakat sebagai sebuah sumber ekonomi yang tidak mempunyai peran dan potensi sudah saatnya untuk dirubah menjadi sesuatu yang mempunyai daya saing dengan sumber ekonomi lainnya yang selama ini dikelola oleh daerah dan bangsa. M enjawab atas

${ }^{40}$ L ihat: A bdul W ahab M uhamini, K ajian ..... 43

${ }^{41}$ Lihat: Nurul Huda, dkk, 2012, K euangan... .180. Lihat: UU Nomor 23 Tahun 2011, psl 26.

${ }^{42}$ Lihat: A rief M ufraini, 2008, A kuntansi...... 192.

${ }^{43}$ E riesudewo berpendapat bahwa di Indonesia zakat masih dikelola secara tradisional dengan cirinya dikelola setengah hati, tidak full time, tidak profesional, tidak punya program yang mampu merubah status mustahiq, tak jelas hak dan kewajiban amil, lebih hanya sekedar menggugurkan kewajiban berzakat serta tidak punya cita-cita dan visi ke depan. U raian ini dapat dilihat dalam artikelnya yang berjudul "Perubahan Paradigma \& Reintrepretasi Pendayagunaan Zakat", (http://eriesudewo.blogspot.co.id/2007/09/), diakses pada tanggal 08 Juni 2016. 
kondisi daerah yang dirasakan potensi zakat belum terkelola dengan baik serta lahirnya UU Nomor 23 Tahun 2011 tentang Zakat yang diikuti dengan Peraturan di bawahnya, Pemerintah kota Palu telah menyikapinya dengan melakukan rerkruitmen pengurus yang baru. A bdul Chaer mengatakan bahwa dalam rangka membentuk pengurus baru Badan A mil Zakat Nasional Daerah sebagaimana amanah undang-undang, maka pihaknya telah membentuk Panitia Seleksi Calon Pimpinan Baznas kota Palu sesuai ketentuan yang berlaku, dan panitia dimaksud telah melaksanakan tugasnya dengan baik. Hasil yang diperoleh dari panitia mendapatkan 5 (lima) orang calon pimpinan Badan A mil Zakat $N$ asional kota Palu yang untuk periode pertama sebagaimana amanah undang-undang. ${ }^{44}$

Pembentukan BAZNAS kota Palu sebagai realisasi dari undang-undang merupakan langkah baru dalam merubah paradigma atau pemahaman pengelolaan zakat yang selama ini berlaku dalam masyarakat di kota Palu. Jika selama ini pengelolaan zakat kurang jelas kedudukannya dalam sistem pemerintahan, maka lahirnya undang-undang hasil revisi undang-undang zakat sebelumnya menjadi sangat jelas; dimana dijelaskan bahwa Badan A mil Zakat Nasional adalah lembaga pemerintah non struktural. ${ }^{45} \mathrm{~K}$ edudukan BAZNAS yang demikian itu menunjukkan adanya komitmen yang sungguh-sungguh dari Pemerintah. Nasaruddin U mar ketika memberikan pandangannya terhadap gugatan atas UU Nomor 23 Tahun 2011 di M ahkamah Konstitusi seperti dikutip oleh Y usuf Wibisono mengatakan bahwa "zakat adalah ibadah mahdæ̧h dengan kedudukan yang khusus dalam Islam yakni "khuz min amwabihim", maka otoritas pengumpul zakat adalah "pemerintah." Zakat harus dikelola secara melembaga sesuai syari'at Islam, amanah, kemanfaatan, keadilan, kepastian hukum, terintegrasi, dan akuntabilitas sehingga dapat meningkatkan efektivitas dan efisiensi pelayanan dalam pengelolaan zakat. ${ }^{46}$ Penetapan undang-undang pengelolaan zakat tentunya mempunyai norma yang menjadi dasar berlakunya. Di rumuskan dan ditetapkannya perundang-undangan zakat di Indonesia untuk menjadi kaidah yang mengikat dan mengatur bagi masyarakat. Walaupun lahirnya undang-undang

${ }^{44}$ A bdul Chaer, Wawancara, tanggal 09 Juni 2016 di kantor Walikota Palu. Lebih Ianjut beliau menyampaikan bahwa calon pimpinan yang diseleksi telah memenuhi syarat sebagaimana di atur dalam perundang-undangan zakat dan peraturan yang ditetapkan oleh Badan A mil Zakat Nasional Pusat. Selain itu, bahwa upaya pembentukan BAZNAS kota Palu telah jelas disebutkan dalam Sk. Dirjen Bimbingan M asyarkat Islam K ementerian A gama RI; jadi pemerintah kota Palu wajib menindak lanjuti hal tersebut.

${ }^{45}$ UU N omor 23 Tahun 2011 pasal 5 ayat (3).

${ }^{46} \mathrm{~L}$ ihat: $Y$ usuf W ibisono, M engelola... 177. 
dimaksud tidaklah berdiri sendiri melainkan mempunyai keterkaitan dengan aspek lainnya disebabkan pelaksanaan zakat merupakan sarana komunikasi antar sesama manusia. ${ }^{47}$

Berdasarkan hal-hal di atas, maka pengelolaan zakat yang maju hanya akan dapat tercapai bila seluruh komponen yang terkait dalam pengelolaan zakat mempunyai komitmen yang sama dan satu untuk mengembangkan zakat kearah yang lebih baik. Untuk dapat terealisasi komitmen tersebut Badan A mil Zakat Nasional harus memiliki visi, misi, dan tujuan pengelolaan zakat yang terbingkai dalam sebuah lembaga kerja yaitu "A mil Zakat". M engelola zakat kota Palu harus berangkat dari penentuan visi, misi dan tujuan. Penentuan visi menjadi Badan A mil Zakat Nasional yang amanah, transparan dan profesional adalah sebuah gagasan baru untuk membangun kepercayaan public sejak awal. Konsep amanah, transparan dan profesional menjadi sebuah tuntutan zaman sekarang terhadap pengelolaan organisasi atau lembaga. Semakin amanah pengelola suatu organisasi atau lembaga maka tingkat kepercayaan publik akan semakin meningkat pula, sehingga peluang untuk membangun hubungan kerja semakin baik pula. Hal serupa berlaku pada sikap transparansi dan profesional mengelola organisasi termasuk di dalamnya adalah badan amil zakat nasional daerah.

Harapan visi yang demikian itu juga menuntut adanya misi pengelolaan, yaitu: adanya upaya meningkatkan kesadaran umat untuk membayar zakatnya melalui amil zakat; adanya upaya meningkatkan penghimpunan dan pendayagunaan zakat daerah dengan mendasarkan ketentuan syariah Islam dan prinsip manajemen; berupaya menumbuh kembangkan sikap dan perilaku amil zakat yang selalu amanah, transparan, profesional, dan bertanggung jawab; mengupayakan adanya sistem database atau pusat data zakat daerah; berupaya merealisasikan hasil pengumpulan zakat dalam menanggulangi kemiskinan di kota Palu dengan pola sinergisitas dan koordinasi dengan lembaga terkait.

Pencapaian visi, misi di atas, perlu diikuti dengan langkah-langkah strategis antara lain: membuat program-program sosialisasi secara intens ke seluruh lapisan masyarakat yang berada dalam lingkup kota Palu; membuat pola dan panduan pengelolaan yang terarah dalam meningkatkan penghimpunan dan pendayagunaan hasil zakat; membuat

\footnotetext{
${ }^{47}$ Lihat: A hmadan B. Lamuri, K onsepsi... 99-100.
} 
standart operasional prosedur (SOP) dalam tata kelola zakat; membuat standart penanggulangan kefakiran, kemiskinan, atau mustahik lainnya ke kegiatan produktif; membuat memorandum of understanding ( $\mathrm{MoU}$ ) bersama instansi dan lembaga terkait. Komitmen bersama dalam kelembagaan menjadi sarana penting merealisasikan apa yang telah dicanangkan dalam visi, misi, dan tujuan organisasi. ${ }^{48}$

\section{Simpulan}

K eberhasilan pengelolaan zakat akan banyak ditentukan oleh cara kerja amil zakat. A mil sebagai salah satu dari mustahik juga sebagai kelompok orang yang mempunyai tugas dan tanggung jawab mengelola zakat. Dukungan keberhasilan pengelolaan zakat oleh muzakki, mustahik, serta pihak lain yang terkait apabila telah terbangun pandangan yang sama atau sejalan dalam memahami pengelolaan zakat. Jika selama ini pengelolaan zakat masih bertumpu pada sistem yang tradisional, maka kondisi ini perlu dirubah dengan paradigma baru yang lebih berorientasi pada "semakin besar dan meningkatnya manfaat serta peran zakat itu dalam menanggulangi kemiskinan yang menjadi bagian dari penyakit sosial masyarakat." Oleh karena itu, harus ada perubahan paradigma pihak muzakki, mustahik, serta amil untuk mengelola zakat dengan selalu mengedepankan prinsip manajemen, sifat amanah, transparan, serta profesional demi terwujudnya masyarakat fakir dan miskin yang lebih meningkat harkat dan martabatnya serta menjadi komunitas wajib zakat. Lahirnya UU Nomor 23 Tahun 2011 menjadi landasan yuridis lahirnya kinerja kelembagaan dalam penyelesaian masalah zakat di Indonesia. Terbentuknya BAZNAS kota Palu adalah bagian dari upaya merealisasikan komitmen nasional dalam pengelolaan zakat.

\section{D aftar Pustaka}

Al-Qur' an dan Terjemahnya.

A sqalany, Ibnu Hajar al-, Subulussalam J uz II, M aktabah al-J umhuriyah al-A rabiyah, t.th.

\footnotetext{
${ }^{48}$ L ihat: Peraturan BAZNAS Nomor 04 Tahun 2014 tentang Pedoman Penyusunan Rencana Kerja dan Anggaran Tahunan Badan Amil Zakat Nasional Propinsi, dan Badan Amil Zakat Nasional K abupaten/K ota.
} 
Attamimi, Faisal S. Laporan Hasil Penelitian tentang "Perspektif M asyarakat kota Palu terhadap Pengelolaan Zakat; yang diterbitkan dalam jurnal "Hunafa" vol. 5 nomor 3 tahun 2008.

Azizy, A. Qadry, Membangun Fondasi Ekonomi Umat, Meneropong Prospek B erkembangnya Ekonomi Islam, (Y ogyakarta: Pustaka Pelajar, 2004).

Bulungo, A milin A., Menata Manajemen BAZNAS dalam Mengentaskan Komiskinan Berbasis Pemberdayaan Masyarakat di kota Palu, (makalah) disampaikan dalam kegiatan seleksi Calon Pimpinan BA ZNAS kota Palu tahun 2016 di Palu.

Chaudhry, Muhammad Sharif, Sistem Ekonomi Islam Prinsip Dasar, (Jakarta: Prenadamedia, 2012)

Eriesudewo, Perubahan Paradigma \& Reintrepretasi Pendayagunaan Zakat, http://eriesudewo.blogspot.co.id/2007/09/, 2007.

Hasanuddin \& M uhammad Ridha, Paradigma Baru M anajemen Zakat, dikutip dari laman: http://koneksi-indonesia.org/2013/paradigma-baru-manajemen-zakat/; diakses pada tanggal 25 M ei 2016.

Huda, Nurul (et.al), K euangan Publik Islami Pendekatan Teoritis dan Sejarah, (J akarta: Kencana, 2012).

Chaer, A bd. (W awancara), Palu, tanggal 09 J uni 2016.

Lamuri, Ahmadan B., Konsepsi Hukum Islam tentang Amil Zakat dan Korelasinya dengan Undang-undang Nomor 38 Tahun 1999, tesis (tidak diterbitkan), (M akassar, IAIN A lauddin, 2004).

Latima, Djasman,W awancara, tanggal 09 J uni 2016, di Palu

M ahfudh, Sahal, Nuansa Fiqh Sosial, (Y ogyakarta: LK iS, 1994).

Mufraini, A rief, Akuntansi dan Manajemen Zakat (Mengkomunikasikan Kesadaran \& M embangun J aringan), (J akarta: K encana Prenada M edia, 2008).

M ughniyah, M uhammad J awad, Fiqh Lima M azhab (terj.), (Jakarta: L entera, 2011).

M uhaimin, A bdul Wahab, K ajian Islam A ktual, (J akarta: Gaung Persada Press, 2011).

Muhammad \& Ridwan Mas'ud, Zakat dan Kemiskinan Instrumen Pemberdayaan Ekonomi Umat, (Y ogyakarta: UII Press, 2005).

Muslim, S

M utđ̧hhari, M urthadha, M anusia dan A lam Semesta K onsepsi Islam tentang Jagat Raya, (terj.) oleh Ilyas Hassan, (J akarta: L entera, 2006).

Peraturan Pemerintah Nomor 14 Tahun 2014.

Peraturan BAZNAS N omor: 04 T ahun 2014 tentang Pedoman Penyusunan Rencana K erja dan Anggaran Tahunan Badan A mil Zakat Nasional, Badan A mil Zakat Nasional Propinsi, Badan A mil Zakat Nasional K abupaten/K ota.

Permono, Sjechul Hadi, Formula Zakat Menuju Kesejahteraan Sosial, (Surabaya: CV. Aulia, 2005). 
Qadir, A bdurrachman, Zakat dalam Dimensi M ahdhah \& Sosial, (J akarta: Raja Grafindo Persada, 2001).

Qardhawi, Y usuf al-, Teologi Kemiskinan Dokrtin Dasar \& Solusi Islam atas Problem Kemiskinan, (terj.) oleh A. Maimun \& A. Wahid (Y ogyakarta: Pustaka Pelajar, 2002).

, Hukum Zakat (terj.) oleh Salman Harun \& Didin Hafidhuddin, (B andung: Mizan, 1996).

Sahroni, Oni \& A diwarman Karim, M aqashid Bisnis \& K euangan Islam Sintesis Fikih dan Ekonomi, (Jakarta: Rajawali Press, 2015).

ash-Shiddieqy, T.M . Hasbi, Pedoman Zakat, (Semarang: Rizki Putra, 2009).

Surat Keputusan Dirjen Bimbingan Masyarakat Islam Kemenag RI, Nomor: Dj.II/568 Tahun 2014, tentang Pembentukan B adan A mil Zakat Nasional Kabupaten/K ota seIndonesia.

Undang-undang Nomor 23 Tahun 2011 tentang Pengelolaan Zakat.

Wibisono, Y usuf, Mengelola Zakat Indonesia, Diskursus Pengelolaan Zakat Nasional, (J akarta: Prenada M edia Group, 2015).

Yafie, Ali, Menggagas Fiqh Sosial dari Soal Lingkungan Hidup, A suransi, hingga Ukhuwah, (B andung: M izan, 1992).

Y anggo, Huzaemah T., M asail Fiqhiyah, Kajian Hukum Islam Kontemporer, (Bandung: A ngkasa, 2005).

Zabir, Wawancara, tanggal 08 J uni 2016 di Palu.

al-Zuhaily, Wahbah, Zakat Kajian Berbagai Mazhab, diterjemahkan oleh A gus Effendi, (B andung: Remaja Rosdakarya, t.th).

------, Figh al-Islam wa Adillatuhu jilid 3, (terj.) Abdul Hayyie, dkk. (Depok; Gema Insani Press, 2011).

350 | al-Maslahah: - Vofume 12 Nomor 2 Oktober 2016 